\title{
A laser device for fusion of nasal mucosa
}

\author{
Michael Larson*, Valmiki Sooklal, Jesse McClure, Luke Hooper, Jason Sieber \\ From 2nd Scientific Meeting of the Head and Neck Optical Diagnostics Society \\ San Francisco, CA, USA. 23-24 January 2010
}

A patent pending device has been created, and successfully used, to fuse tissue membranes as an alternative to sutures or staples. The joining, or coaptation, is accomplished through the controlled application of laser heating to induce protein denaturation and subsequent renaturation across the interface. Lasers have been used by a number of researchers to close wounds in controlled laboratory tests over the last 15 years. Many encouraging results have been obtained; however, no commercial delivery systems are currently available. This is due primarily to two factors: requiring an inordinate amount of experience on the part of the operator to detect changes in tissue appearance, and attempting to achieve general applicability for multiple tissue systems. The present device overcomes these barriers as it is tailored for the particular application of septal laser fusion, namely for the coaptation of mucoperichondrial membranes.

The important parameters involved in fusing biological tissues using radiation from laser sources are identified. The development of the device followed from computational modeling of the fusion process based on engineering first-principles from heat transfer, fluid dynamics and optics, and from experimental results on a particular tissue system. The experiments were designed and analyzed using orthogonal arrays, employing a subset of the relevant parameters, i.e., laser irradiance, dwell time and spot size, for a range of wavelengths. The in vitro fusion experiments employed $1 \mathrm{~cm}$ by $1 \mathrm{~cm}$ sections of equine nasal mucosa having a nominal thickness of $1 \mathrm{~mm}$.

Submit your next manuscript to BioMed Central and take full advantage of:

- Convenient online submission

- Thorough peer review

- No space constraints or color figure charges

- Immediate publication on acceptance

- Inclusion in PubMed, CAS, Scopus and Google Scholar

- Research which is freely available for redistribution

Submit your manuscript at www.biomedcentral.com/submit
C Biomed Central 